\title{
The composition of interfacial material from skim milk foams
}

\author{
S. Kamath, ${ }^{*}$ R. E. Webb,† and H. C. Deeth ${ }^{\star 1}$ \\ *School of Agriculture and Food Sciences, and \\ †Centre for Microscopy and Microanalysis, University of Queensland, Brisbane, Queensland 4072, Australia
}

\begin{abstract}
The foaming properties of skim milk vary with temperature of foaming in the range from 5 to $85^{\circ} \mathrm{C}$, with foams of maximum stability being formed at approximately $45^{\circ} \mathrm{C}$. This paper reports the significance of different milk fractions in the foam and concludes that the micellar casein fraction plays an important role in stabilization of milk foam formed at higher temperatures. This finding was supported by the fact that added calcium chloride increased and calcium-chelating agents decreased foam stability. These effects were attributed to the increase and decrease, respectively, in the amount of micellar casein in the milk. Furthermore, bubble ghost material sedimented by low-speed centrifugation of foam was found to contain predominantly caseins, and electron micrographs of foams formed at $45^{\circ} \mathrm{C}$ clearly showed casein micelles spread over the interface. However, other structures observed in the electron micrographs suggest that soluble milk proteins and possibly polar lipids are also present in the foams and play a role in formation of milk foams.
\end{abstract}

Key words: skim milk, foam, casein micelles, electron microscopy

\section{INTRODUCTION}

Caseins and whey proteins are the major macromolecular surfactants present in milk and they tend to adsorb at the air-serum interface of milk foams (Anderson and Brooker, 1988). The foamability of milk is determined by the rapidity with which the proteins can move to the air-liquid interface, whereas foam stability is determined by the ability of the adsorbed proteins to form a cohesive viscoelastic film via formation of intermolecular bonds (Damodaran, 1997).

Temperature affects the conformation of milk proteins and their distribution between the serum and colloidal phases of milk (Downey and Murphy, 1970; Law,

Received September 19, 2010

Accepted February 18, 2011.

${ }^{1}$ Corresponding author: h.deeth@uq.edu.au
1996). In doing so, it affects the molecular parameters for foaming such as molecular flexibility, hydrophobicity, and accessibility of free thiol groups (Downey and Murphy, 1970; Law et al., 1994; Kilara and Harwalkar, 1996). In other words, temperature determines the physical phenomena such as foamability of milk and stability of milk foam by altering the protein composition and protein-protein interactions at the air-liquid interface of milk foams. Kamath et al. (2008) found that the foaming properties of skim milk varied with temperature in the range from 5 to $85^{\circ} \mathrm{C}$, with skim milk foams formed at $45^{\circ} \mathrm{C}$ showing maximum stability.

When milk foam collapses, the interfacial envelopes that once surrounded the air bubbles remain in the milk in the form of flat membranous structures known as "bubble ghosts" (Sharp et al., 1936; Mulder and Walstra, 1974; Brooker, 1985). It is believed that these bubble ghosts can be used to determine the composition of the air-serum interface of milk foams. Some researchers (Brooker, 1985; Anderson et al., 1987; Ward et al., 1996) have attempted to study the interfacial composition of milk foams but the investigations were restricted to studying the protein composition of the bubble ghosts isolated from milk foamed at a single temperature; for example, $6^{\circ} \mathrm{C}$ (Brooker, 1985; Anderson et al., 1987) or room temperature (Ward et al., 1996). Borcherding et al. (2008) studied the interface of skim milk foams formed at $50^{\circ} \mathrm{C}$ using transmission electron microscopy. The above investigations concluded that the air-serum interface of milk foams was made up of soluble caseins and whey proteins, with casein micelles not forming an integral part of the air-serum interface.

The aims of this investigation were to determine the interfacial composition of skim milk foams as a function of temperature and to relate interfacial composition to the foam stability pattern of skim milk.

\section{MATERIALS AND METHODS}

\section{Materials and Preparation of Reconstituted Milk}

Low-heat skim milk powder (LHSMP) was supplied by Murray Goulburn Co-Operative (Melbourne, Australia). It was manufactured with a preheat treatment of $72^{\circ} \mathrm{C}$ for $30 \mathrm{~s}$. 
Reconstituted milk was prepared by dissolving the LHSMP in MilliQ water (Millipore, Billerica, MA) at a concentration of $85 \mathrm{~g}$ of solids/L. The milk sample was left to hydrate overnight at $4^{\circ} \mathrm{C}$. Sodium azide $(0.5 \mathrm{~g} / \mathrm{L})$ was added to prevent microbial growth.

\section{Foamability and Foam Stability Measurements}

Milk was foamed using the foaming apparatus described by Kamath et al. (2008). Foamability was expressed as the total volume of foam $(\mathrm{mL})$ obtained from $50 \mathrm{~mL}$ of milk immediately after bubbling. Foam stability was expressed in terms of foam half-life, the time (min) required for the foam to collapse to half its original volume.

\section{Preparation of Simulated Milk Ultrafiltrate and Casein and Whey Protein Fractions of Milk}

Simulated milk ultrafiltrate (SMUF) was prepared by the procedure outlined by Jenness and Koops (1962). Sodium azide $(0.5 \mathrm{~g} / \mathrm{L})$ was added to prevent microbial growth.

Reconstituted LHSMP (approximately $10 \mathrm{~mL}$ per tube) was separated into its micellar and nonmicellar phases by ultracentrifugation at $100,000 \times g$ for $90 \mathrm{~min}$ at $25^{\circ} \mathrm{C}$ using a Beckman L8-70M ultracentrifuge with a $70 \mathrm{I}$ Ti rotor (Beckman Coulter, Inc., Brea, CA). The supernatant phase, including the opalescent layer (located just above the micellar pellet) and the fat layer, was immediately decanted, leaving a firm micellar pellet. The pellet was mixed with a small amount of SMUF, ground into a paste using a mortar and pestle, and redispersed in SMUF by stirring for $24 \mathrm{~h}$ at $4^{\circ} \mathrm{C}$. The centrifugation and resuspension steps were repeated to remove residual whey protein. The volume of the resultant solution was adjusted using SMUF, so that the solution contained casein in the same concentration as that in the original milk. The resultant solution is hereafter referred to as the casein fraction.

The turbid ultracentrifugal supernatant was divided into 2 equal portions. One portion was used directly for foaming studies. The other portion was defatted by centrifugation at $60,000 \times g$ for $30 \mathrm{~min}$ at $25^{\circ} \mathrm{C}$. The fat layer was carefully removed using a pipette and the solution was filtered through Filtech No. 1893-150 filter paper and a $0.22-\mu \mathrm{m}$ nylon filter (Millex-GP syringedriven filter unit; Millipore) to obtain a clear yellow solution, which was used for foaming studies.

\section{Protein Content and Composition of Collapsed Foam}

Reconstituted LHSMP $(2 \times 50-\mathrm{mL}$ portions $)$ was foamed at $5,25,45,65$, and $85^{\circ} \mathrm{C}$. The bulk liquid below the foam was removed with a pipette soon after foaming and at the half-life of the foam. The total protein content of the collapsed foam and the bulk liquid was determined using a Leco CNS-2000 combustive analyzer (Leco Australia Pty. Ltd, Castle Hill, NSW, Australia) and a Varian PRO inductively coupled plasma optical emission spectrometer (Varian Australia Pty. Ltd, Mulgrave, Vic., Australia). The protein composition of the collapsed foam and bulk liquid was analyzed by reducing SDS-PAGE as described below.

\section{Gel Electrophoresis}

Reducing and nonreducing SDS-PAGE was used to separate, identify, and quantify proteins in milk, its casein and whey protein fractions, and foam and milk pellets. All buffers and reagents used for gel electrophoresis were prepared using procedures outlined in the Bio-Rad Mini-Protean III manual (Bio-Rad, Richmond, CA). Samples were mixed 1:2 (vol:vol) with sample buffer. For SDS-PAGE under nonreducing conditions, the samples were heated at $45^{\circ} \mathrm{C}$ for $5 \mathrm{~min}$ in a water bath. For SDS-PAGE under reducing conditions, $5 \% \beta$-mercaptoethanol was added to the samples followed by heating at $95^{\circ} \mathrm{C}$ for $5 \mathrm{~min}$ in a water bath. The samples were cooled to ambient temperature and loaded onto an SDS gel made up of stacking and separating gels containing 5 and $15 \%$ acrylamide, respectively. The loading volumes were adjusted to ensure that all wells contained the same amount of protein. The gel was run in a Mini-Protean system (Bio-Rad) at $200 \mathrm{~V}$ using a Bio-Rad power supply unit (Power Pac 3000). The protein bands separated on the gel were fixed using fixative solution containing $40 \%$ methanol and $10 \%$ acetic acid followed by overnight staining on a shaker using colloidal Coomassie blue or modified Neuhoff stain (0.1\% Coomassie G-250 in 3\% phosphoric acid and $34 \%$ methanol solution containing $17 \%$ ammonium sulfate). The gel was destained by washing 4 times with $1 \%$ acetic acid and preserved in $0.1 \%$ acetic acid. The destained gel was scanned using a densitometer (GS800, Bio-Rad). Quantitative estimation of the protein bands on the scanned image was performed using Quantity One software (Bio-Rad). The relative quantities of proteins in a sample were determined by measuring the intensity of bands corresponding to the various proteins and expressing this intensity as a percentage of the total bands measured.

\section{Separation and Analysis of Interfacial Proteins}

The sedimentable interfacial proteins in collapsed foams were isolated using an adaptation of the centrifugation technique used by Brooker (1985). Recon- 
stituted skim milk $(2 \times 50$-mL portions $)$ was foamed at $5,25,45,65$, and $85^{\circ} \mathrm{C}$ using the method outlined by Kamath et al. (2008). The liquid below the foam was removed immediately using a pipette and the foam was then allowed to collapse overnight at $4^{\circ} \mathrm{C}$ ). The control samples consisted of the same milk $(2 \times 50-\mathrm{mL}$ portions) equilibrated to $5,25,45,65$, and $85^{\circ} \mathrm{C}$, cooled to room temperature, and then held overnight at $4^{\circ} \mathrm{C}$, along with the collapsing foam samples.

The collapsed foam samples were weighed and, along with the corresponding control samples of equal weights, were centrifuged at $3,000 \times g$ for $15 \mathrm{~min}$ at $20^{\circ} \mathrm{C}$ using an Eppendorf 5702R centrifuge (Eppendorf International, Hamburg, Germany). The supernatant was carefully removed with a pipette and the pellet was resuspended in deionized water and recentrifuged as above. The pellet was then resuspended in $1.0 \mathrm{~mL}$ of deionized water. The sedimentable material isolated from collapsed foam is referred to herein as the foam pellet and the sedimentable material isolated from the control sample is referred to as the milk pellet.

The protein content of the foam and milk pellets was determined by the micro-Lowry assay (Lowry et al., 1951). The proteins in the foam and milk pellets were analyzed using reducing and nonreducing SDS-PAGE. The particle size of the foam and milk pellets was determined using the procedure outlined below. The pellets described above were washed and resuspended in SMUF instead of deionized water. The SMUF was filtered through a $0.22-\mu \mathrm{m}$ filter before use.

\section{Determination of Average Casein Micelle Size}

Average casein micelle size in milk and resuspended foam and milk pellets were determined by photon correlation spectroscopy using a Malvern Zetasizer (Malvern Instruments Ltd., Malvern, UK). A $20-\mu \mathrm{L}$ aliquot of milk or pellet suspension was mixed with $3.0 \mathrm{~mL}$ of SMUF. The SMUF was filtered through a $0.22-\mu \mathrm{m}$ filter before use. Average particle diameter was determined in triplicate at $25^{\circ} \mathrm{C}$.

\section{Preparation of Reconstituted Milk with Added Calcium-Chelating Agents and Calcium Chloride}

Reconstituted LHSMP containing added trisodium citrate, EDTA, sodium hexametaphosphate (SHMP), or calcium chloride were prepared as outlined by Udabage et al. (2000). The LHSMP was reconstituted in MilliQ water at a concentration of $150 \mathrm{~g}$ of solids/L. The milk was stirred on a magnetic stirrer for $1 \mathrm{~h}$ and then allowed to stand at room temperature $\left(22^{\circ} \mathrm{C}\right)$ for 2 $\mathrm{h}$. The stock salt solutions used were $100 \mathrm{~m} M$ trisodium citrate, $200 \mathrm{~m} M$ EDTA $\left(\mathrm{Na}_{2}\right), 100 \mathrm{~m} M$ SHMP, and 500 $\mathrm{m} M \mathrm{CaCl}_{2} \cdot 2 \mathrm{H}_{2} \mathrm{O}$. The salt solutions were added dropwise to the above-mentioned milk with continuous stirring. The $\mathrm{pH}$ of the milk was adjusted to 6.65 by the drop-wise addition of $1 \mathrm{M} \mathrm{HCl}$ or $1 \mathrm{M} \mathrm{NaOH}$, and the milk was diluted to $85 \mathrm{~g}$ of solids/L using MilliQ water. Sodium azide $(0.5 \mathrm{~g} / \mathrm{L})$ was added to prevent microbial growth. All milk had final $\mathrm{pH}$ of $6.65 \pm 0.02$ at room temperature.

\section{Transmission Electron Microscopy of Milk Foams}

Foam was formed in skim milk at $45^{\circ} \mathrm{C}$. A plastic loop (5-mm diameter) that had been set into the cap of a 5 -mL bottle was dipped into the foam and quickly removed. The foam supported in the plastic loop was then fixed for $30 \mathrm{~min}$ at room temperature in glutaraldehyde vapor by sealing the loop into a 5 -mL bottle containing $2.5 \mathrm{~mL}$ of $25 \%$ glutaraldehyde. The fixed foam was transferred on the loop to osmium tetroxide (4\%) vapor for $1 \mathrm{~h}$ at room temperature. It was briefly dipped into molten $2 \%$ agar at $40^{\circ} \mathrm{C}$, allowed to solidify, and dipped a second time. The foam was then dehydrated using, sequentially, 50, 60, 70, 80, 90, and $100 \%$ ethanol for 10 min each and then in Spurr resin, 2:1, $1: 1$, and $1: 2$ for $1 \mathrm{~h}$ each and then immersed in $100 \%$ Spurr resin overnight for penetration of the resin. The resin was polymerized at $60^{\circ} \mathrm{C}$ for $2 \mathrm{~d}$. Thin sections were cut on a Lieca Ultracut S ultramicrotome (Leica Microsystems Pty. Ltd, North Ryde, NSW, Australia), stained with uranyl acteate and lead citrate, and examined at an accelerating voltage of $80 \mathrm{kV}$ in a Jeol 1010 transmission electron microscope (JEOL Australasia Pty. Ltd., Sydney, NSW, Australia).

\section{RESULTS AND DISCUSSION}

\section{Foamability and Foam Stability of Casein and Whey Protein Fractions of LHSMP}

Figures $1 \mathrm{a}$ and $1 \mathrm{~b}$ show the patterns of foamability and foam stability, respectively, of milk and pelleted casein, ultracentrifugal supernatant, and defatted ultracentrifugal supernatant fractions. Foamability of milk and its fractions increased progressively with increasing temperature, with the exception of the nondefatted ultracentrifugal supernatant, which showed a decrease in foamability at $25^{\circ} \mathrm{C}$ (Figure 1a). The foam stability of the casein fraction, nondefatted ultracentrifugal supernatant, and defatted ultracentrifugal supernatant varied in their foam stability patterns with increasing temperature.

The casein fraction of milk formed extremely stable foam at 5,25 , and $45^{\circ} \mathrm{C}$ (Figure $1 \mathrm{~b}$ ) As in the case of the parent skim milk, the foam stability of the casein 

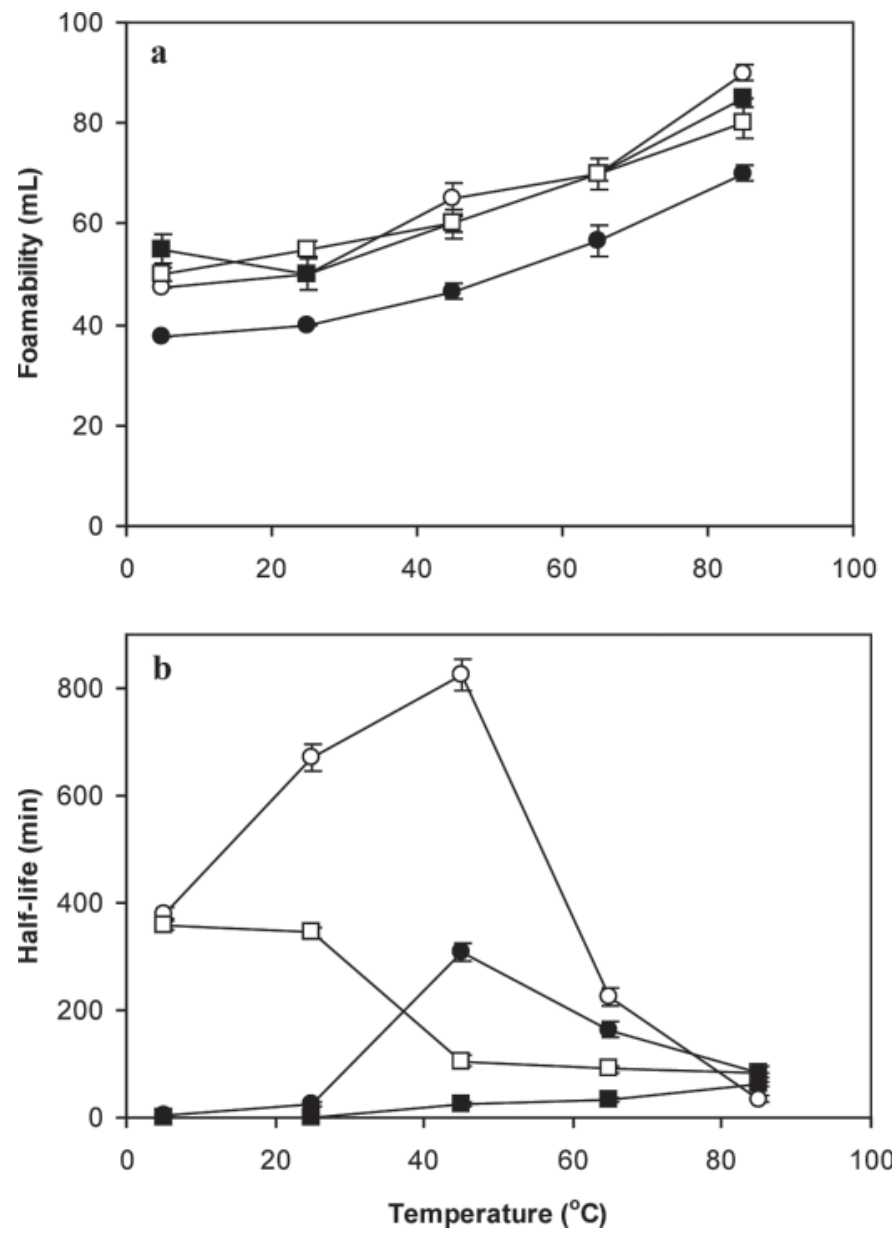

Figure 1. Foamability (a) and foam stability (half-life, b) of reconstituted low-heat skim milk powder (LHSMP) and its casein and ultracentrifugal supernatant fractions as a function of temperature: $(\bullet)$ reconstituted LHSMP, $(\bigcirc)$ casein, $(\square)$ defatted ultracentrifugal supernatant, (ם) ultracentrifugal supernatant. Values presented are the mean of 3 determinations \pm SD. The range of percentage standard deviation for foamability and foam stability were 1 to $4 \%$ and 1 to $10 \%$, respectively.

fraction peaked at $45^{\circ} \mathrm{C}$ (half-life $>800 \mathrm{~min}$ ) after which a pronounced reduction in foam stability occurred at $65^{\circ} \mathrm{C}$. At $85^{\circ} \mathrm{C}$, the foam was much less stable, with a half-life of $\sim 35$ min (Figure 1b). The exceptional stability of the casein fraction compared with the parent skim milk, especially in the temperature range from 5 to $45^{\circ} \mathrm{C}$ (half-life at $45^{\circ} \mathrm{C}$ of approximately $300 \mathrm{~min}$ ), could be partly because this fraction was essentially free of foam-inhibiting substances such as fat, partial glycerides, free fatty acids, and phospholipids (Mulder and Walstra, 1974; Rombaut and Dewettinck, 2006). Oortwijn and Walstra (1979) found that the amount of protein adsorbed onto the surface of milk fat globules when the fat globules were homogenized in a dispersion of washed casein micelles was twice that of skim milk. This suggests that the higher foam stability of the casein fraction compared with skim milk could be due to greater protein adsorption leading to the formation of more dense and therefore more stable films.

The foamability and foam stability pattern of the nondefatted ultracentrifugal supernatant was identical to that reported by Kamath et al. (2008) for raw whole milk and pasteurized homogenized whole milk and can be attributed to the detrimental effects of crystalline fat (Mulder and Walstra, 1974; Walstra et al., 1999; Kamath et al., 2008). The foam stability of the nondefatted ultracentrifugal supernatant was poor, particularly at 5 and $25^{\circ} \mathrm{C}$ (half-life $<0.5 \mathrm{~min}$ ); it increased above $25^{\circ} \mathrm{C}$ and was highest at $85^{\circ} \mathrm{C}$. However, it remained considerably lower than that of the defatted ultracentrifugal supernatant and the casein fraction. This may be due to the low protein content of the ultracentrifugal supernatant caused by removal of most of the casein, thereby enhancing the inhibitory effect of fat.

The foams formed by the defatted ultracentrifugal fraction were most stable at 5 and $25^{\circ} \mathrm{C}$, after which point a marked decrease in foam stability occurred (Figure $1 \mathrm{~b}$ ). Heating above $25^{\circ} \mathrm{C}$ resulted in a progressive increase in turbidity of the sample; turbidity was minimal at $45^{\circ} \mathrm{C}$ and very pronounced at $85^{\circ} \mathrm{C}$. A similar effect was seen on warming SMUF from 25 to $85^{\circ} \mathrm{C}$; heat-induced increases in the turbidity of SMUF and defatted ultracentrifugal supernatant are attributable to insolubilization of calcium phosphate. Milk salts exist in an equilibrium system between the soluble and colloidal phases of milk (Walstra, 1999); heating of milk leads to a decrease in the solubility of calcium phosphate in the milk serum and hence increases the level of colloidal (micellar) calcium phosphate (Holt, 1995). In the ultracentrifugal supernatant, heat-insolubilized calcium phosphate cannot associate with casein micelles and hence precipitates in crystalline form. These crystals can destabilize foams by piercing the foam lamella.

The pattern of foam stability exhibited by skim milk, with a pronounced foam stability peak at $45^{\circ} \mathrm{C}$, was similar to that of its casein fraction (Figure 1b). Caseins are known to adsorb, in preference to whey proteins, to interfaces in dairy emulsions (Darling and Butcher, 1978; Dickinson, 1992; Jeurnink, 1995) and are therefore likely to dominate the air-serum interface of milk foams and play a central role in determining the foaming properties of milk. The patterns of foam stability observed for the ultracentrifugal supernatant and the defatted ultracentrifugal supernatant fractions may not be an accurate reflection of the foaming behavior of the serum phase of milk and it is difficult to ascertain the contribution of the serum phase of milk on it foaming pattern. 


\section{Protein Content and Composition of Collapsed Foam and Bulk Liquid}

The protein contents of the foam and bulk phases of milk were similar to that of unheated, unfoamed milk at all temperatures of foam formation and at the halflife of the foams. All were in the range from 2.70 to $2.84 \mathrm{~g} / 100 \mathrm{~mL}$. This suggests that the protein content of milk foams is similar to that of milk and that milk foams are not notably enriched in proteins. Tables 1 and 2 show the composition of the protein fractions in the foam and bulk phases obtained immediately after foaming milk at $5,25,45,65$, and $85^{\circ} \mathrm{C}$ and at the half-life of the foams, respectively. The protein compositions of the foam and bulk phases of milk were similar irrespective of the temperature at which the milk was foamed, with the proportions of milk proteins in both phases being identical to that in unheated, unfoamed milk. These results concur with the observations of Sharp et al. (1936) that milk proteins occur in foam in the same proportions as in milk.

\section{Protein Composition of Pellets from Foam and Milk}

The relative proportions of caseins in the foam and milk pellets, as determined by densitometry, were very similar to those of unheated, unfoamed milk (Table 3), suggesting that the foam and milk pellets were predominantly made up of caseins. Except for pellets isolated from foams formed at $85^{\circ} \mathrm{C}$ and their corresponding milk pellets, the relative percentage of $\beta$-LG in all pellets was very low $(\leq 1.5 \%$; Figures $2 \mathrm{a}$ and $2 \mathrm{~b})$ compared with its percentage in unheated, unfoamed milk, which was approximately $15 \%$ of the total protein. A sharp increase $(\sim 16 \%)$ was observed in the relative percentage of $\beta$-LG in pellets isolated from foams formed at $85^{\circ} \mathrm{C}$ and their corresponding milk pellets (Figures 2a and $2 \mathrm{~b}$ ).

For pellets isolated from foams formed at $85^{\circ} \mathrm{C}$ and the corresponding milk pellets, the percentage of $\beta$-LG separated by SDS-PAGE under nonreducing conditions was much lower than the percentages separated under reducing conditions (Figure 2). This indicates that most of the $\beta-\mathrm{LG}$ in the $85^{\circ} \mathrm{C}$ pellets was disulfidelinked, mostly in complexes with $\kappa$-casein (Mohammad and Fox, 1987; de Wit, 1990; Law et al., 1994).

\section{Average Casein Micelle Size in Milk and in Pellets from Milk and Foam}

The average diameter of particles in all resuspended foam and milk pellets ranged from 400 to $600 \mathrm{~nm}$, which was at least twice the average diameter of casein micelles in milk samples (approximately 200-250 nm).

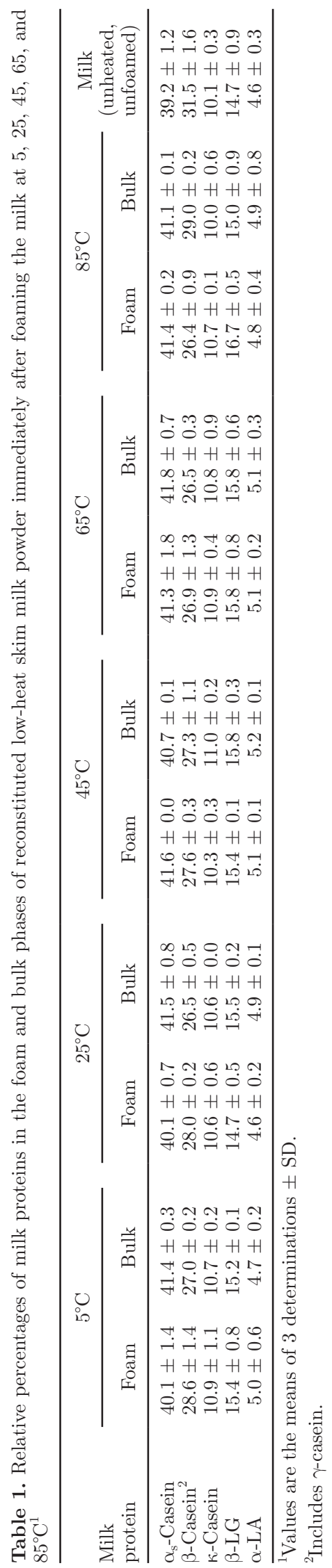

Journal of Dairy Science Vol. 94 No. 6, 2011 
Table 2. Relative percentages of milk proteins in the foam and bulk phases of reconstituted low-heat skim milk powder at the half-life of milk foams formed at $5,25,45,65$, and $85^{\circ} \mathrm{C}^{1}$

\begin{tabular}{|c|c|c|c|c|c|c|c|c|c|c|c|}
\hline \multirow{2}{*}{$\begin{array}{l}\text { Milk } \\
\text { protein }\end{array}$} & \multicolumn{2}{|c|}{$5^{\circ} \mathrm{C}$} & \multicolumn{2}{|c|}{$25^{\circ} \mathrm{C}$} & \multicolumn{2}{|c|}{$45^{\circ} \mathrm{C}$} & \multicolumn{2}{|c|}{$65^{\circ} \mathrm{C}$} & \multicolumn{2}{|c|}{$85^{\circ} \mathrm{C}$} & \multirow{2}{*}{$\begin{array}{c}\text { Milk } \\
\text { (unheated, } \\
\text { unfoamed) }\end{array}$} \\
\hline & Foam & Bulk & Foam & Bulk & Foam & Bulk & Foam & Bulk & Foam & Bulk & \\
\hline$\alpha_{\mathrm{s}}$-Casein & $39.2 \pm 1.3$ & $40.8 \pm 2.3$ & $41.2 \pm 1.2$ & $41.7 \pm 1.1$ & $41.5 \pm 0.2$ & $41.2 \pm 0.7$ & $41.2 \pm 0.2$ & $41.2 \pm 0.9$ & $41.4 \pm 0.0$ & $41.2 \pm 0.1$ & $38.6 \pm 0.8$ \\
\hline$\beta$-Casein ${ }^{2}$ & $28.8 \pm 0.3$ & $28.4 \pm 1.8$ & $28.5 \pm 0.4$ & $26.9 \pm 0.4$ & $27.6 \pm 0.1$ & $27.4 \pm 0.0$ & $26.9 \pm 0.1$ & $27.1 \pm 0.7$ & $26.7 \pm 0.4$ & $28.8 \pm 0.3$ & $30.1 \pm 0.7$ \\
\hline к-Casein & $10.9 \pm 0.0$ & $10.4 \pm 0.4$ & $10.5 \pm 0.2$ & $11.0 \pm 0.6$ & $10.4 \pm 0.2$ & $10.9 \pm 0.1$ & $10.8 \pm 0.2$ & $11.0 \pm 0.3$ & $10.8 \pm 0.2$ & $9.9 \pm 0.1$ & $10.2 \pm 0.1$ \\
\hline$\beta-\mathrm{LG}$ & $15.8 \pm 0.7$ & $15.5 \pm 0.4$ & $14.9 \pm 0.3$ & $15.3 \pm 0.2$ & $15.4 \pm 0.1$ & $15.4 \pm 0.5$ & $15.8 \pm 0.2$ & $15.6 \pm 0.3$ & $16.2 \pm 0.6$ & $15.0 \pm 0.1$ & $15.2 \pm 0.7$ \\
\hline$\alpha-L A$ & $5.3 \pm 0.3$ & $5.0 \pm 0.4$ & $4.9 \pm 0.4$ & $5.1 \pm 0.2$ & $5.1 \pm 0.0$ & $5.1 \pm 0.1$ & $5.2 \pm 0.1$ & $5.1 \pm 0.1$ & $4.8 \pm 0.0$ & $5.0 \pm 0.2$ & $5.0 \pm 0.5$ \\
\hline
\end{tabular}

${ }^{1}$ Values are the means of 3 determinations \pm SD.

${ }^{2}$ Includes $\gamma$-casein.

Table 3. Relative percentages of caseins present in skim milk and its foam and milk pellets ${ }^{1}$

\begin{tabular}{|c|c|c|c|c|c|c|c|c|c|c|c|}
\hline \multirow[b]{3}{*}{ Casein } & \multicolumn{10}{|c|}{ Pellet } & \multirow{3}{*}{$\begin{array}{c}\text { Milk } \\
\text { (unheated, } \\
\text { unfoamed) }\end{array}$} \\
\hline & \multicolumn{2}{|c|}{$5^{\circ} \mathrm{C}$} & \multicolumn{2}{|c|}{$25^{\circ} \mathrm{C}$} & \multicolumn{2}{|c|}{$45^{\circ} \mathrm{C}$} & \multicolumn{2}{|c|}{$65^{\circ} \mathrm{C}$} & \multicolumn{2}{|c|}{$85^{\circ} \mathrm{C}$} & \\
\hline & Foam & Milk & Foam & Milk & Foam & Milk & Foam & Milk & Foam & Milk & \\
\hline$\alpha_{\mathrm{s}}$-Casein & $59.6 \pm 0.9$ & $59.3 \pm 0.8$ & $58.5 \pm 0.6$ & $59.4 \pm 1.6$ & $58.8 \pm 1.3$ & $59.9 \pm 1.3$ & $59.3 \pm 0.9$ & $58.9 \pm 0.7$ & $59.4 \pm 0.8$ & $59.5 \pm 0.6$ & $58.1 \pm 0.6$ \\
\hline$\beta-$ Casein $^{2}$ & $33.2 \pm 0.4$ & $32.7 \pm 0.4$ & $33.3 \pm 0.6$ & $32.5 \pm 1.1$ & $33.0 \pm 1.0$ & $32.1 \pm 1.0$ & $32.7 \pm 0.4$ & $32.9 \pm 0.2$ & $32.2 \pm 0.4$ & $32.8 \pm 0.4$ & $32.5 \pm 0.3$ \\
\hline К-Casein & $7.2 \pm 0.6$ & $8.0 \pm 0.3$ & $8.2 \pm 0.1$ & $8.1 \pm 0.5$ & $8.2 \pm 0.2$ & $8.0 \pm 0.3$ & $8.2 \pm 0.3$ & $8.2 \pm 0.2$ & $8.4 \pm 0.6$ & $7.8 \pm 0.8$ & $9.4 \pm 1.0$ \\
\hline
\end{tabular}

${ }^{1}$ Values are the means of 3 determinations \pm SD.

${ }^{2}$ Includes $\gamma$-casein. 

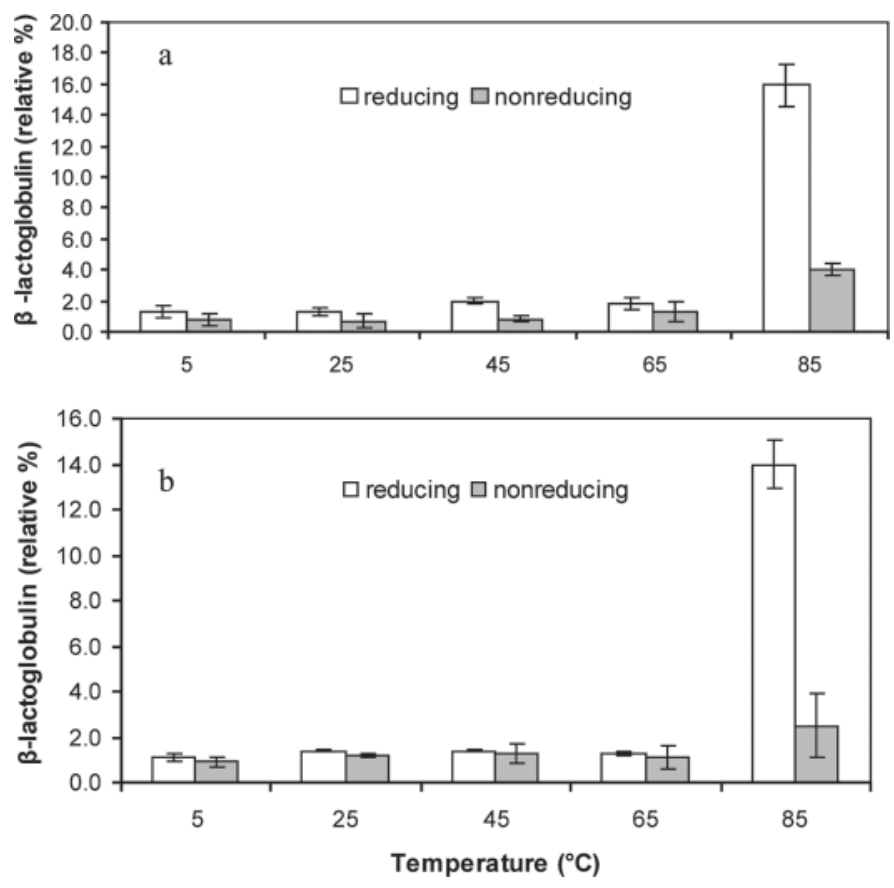

Figure 2. Average proportion $(\mathrm{n}=3)$ of $\beta$-LG in (a) foam pellets and (b) milk pellets isolated from reconstituted low-heat skim milk powder. Values presented are the mean of 3 determinations \pm SD. Reducing: data from reducing SDS-PAGE; Non-reducing: data from non-reducing SDS-PAGE.

The increased size is presumably due to the spreading and physical aggregation of the casein micelles at the foam interface as indicated from electron micrographs of the foam. Foam and milk pellets consist predominantly of caseins, so they are likely to consist of the fraction of casein micelles large enough to sediment at the centrifugal force used in this study $(3,000 \times g)$.

\section{Total Protein Analysis of Interfacial Proteins}

Figure 3 shows the amount of protein sedimented on centrifugation of foam and milk samples from milk foamed at $5,25,45,65$, and $85^{\circ} \mathrm{C}$. The amount obtained from unfoamed milk that had been equilibrated to 5 , $25,45,65$, and $85^{\circ} \mathrm{C}$ and then held overnight at $5^{\circ} \mathrm{C}$ was similar for all temperatures (Figure 3).

No increased sedimentation of proteins occurred upon centrifugation of foams formed at 5 and $25^{\circ} \mathrm{C}$ compared with their corresponding milk pellets (Figure 3). This suggests that the foams are not fortified with milk proteins in the same manner as the foams produced at higher temperatures. Cooling of milk leads to increased dissociation of caseins, especially $\beta$-casein, from micelles (Rose, 1968; Downey and Murphy, 1970). Dissociated caseins are more surface-active than micellar caseins and adsorb preferentially onto the air-serum interface of milk foams (Zhang and Goff, 2004). How- ever, foams formed by nonmicellar caseins are unstable because of the inability of these proteins to interact and form a stable network at the air-serum interface of milk foams (Walstra, 1990; Damodaran, 1997). Moreover, any casein micelles that adsorb onto the interface at these temperatures are unable to aggregate, because casein micelles cannot be made to aggregate at low temperatures when the colloidal stability of micelles is high (Walstra, 1990, 1999). Therefore, it is likely that the lower stability of skim milk foams at 5 and $25^{\circ} \mathrm{C}$ is due to the inability of caseins, both micellar and nonmicellar, to form a stable network at the air-serum interface of milk foams.

Greater sedimentation of proteins occurred on centrifugation of foams formed at 45,65 , and $85^{\circ} \mathrm{C}$ compared with the corresponding milk, with the amount of protein sedimented being highest for foams formed at $45^{\circ} \mathrm{C}$ (Figure 3 ). This suggests that foams formed at the 45,65 , and $85^{\circ} \mathrm{C}$ are enriched in large casein particles. However, the protein contents of the collapsed foam and the bulk liquid below the foam were similar, suggesting that the increased sedimentation of large casein particles in foams formed at 45,65 , and $85^{\circ} \mathrm{C}$ is not because of protein enrichment of the foam, leading to more large particles being sedimented on centrifugation. Casein micelles undergo adsorption-induced spreading and aggregation at the bubble surface (Walstra, 1990, 1999) and this would explain the increase in large particles in foams formed at 45,65 , and $85^{\circ} \mathrm{C}$. The ability of casein micelles to aggregate and form a stable network at the bubble interface is a prerequisite to forming stable foams (Mulder and Walstra, 1974).

Skim milk foams formed at $45^{\circ} \mathrm{C}$ were the most stable. At this temperature, $95 \%$ of the caseins in milk are in the form of micelles (Singh, 1995) and could therefore adsorb in higher amounts onto the air-serum

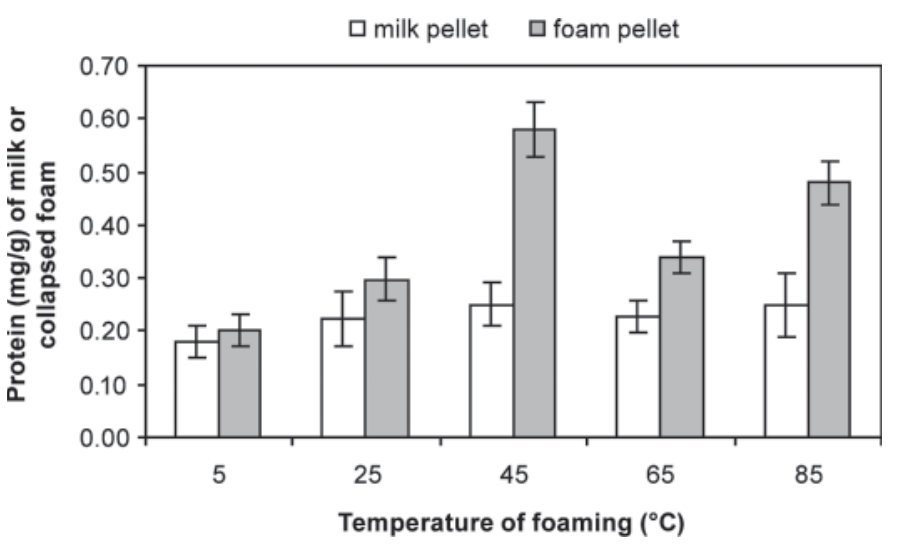

Figure 3. Average amount $(\mathrm{n}=3)$ of protein pelleted in the form of foam and milk pellets from reconstituted low-heat skim milk powder. Values presented are the mean of 3 determinations \pm SD. 

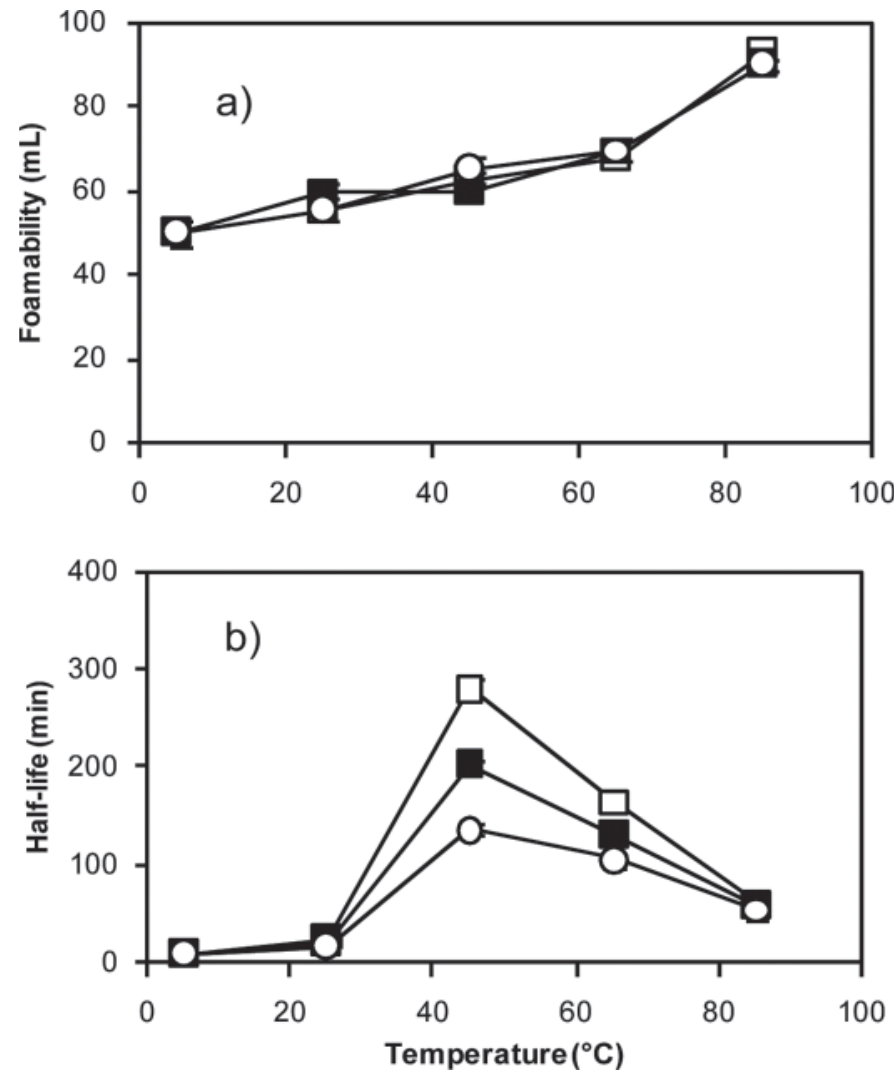

Figure 4. Foamability (a) and foam stability (half-life, b) of reconstituted low-heat skim milk powder (LHSMP) with added trisodium citrate. Values are the mean of 3 determinations $\pm \mathrm{SD}$, using the same lot of LHSMP. The range of percentage standard deviation for foamability and foam stability are 1 to $4 \%$ and 1 to $14 \%$, respectively. ( $\square$ ) Control, (ם) $5 \mathrm{mM}$, (○) $10 \mathrm{~m} M$ trisodium citrate.

interface of milk foams to form a stabilizing network. This increase in the adsorption of micellar casein in foams formed at $45^{\circ} \mathrm{C}$ is consistent with the higher amounts of protein sedimenting upon centrifugation of the collapsed foam.

A pronounced decrease was observed in the amount of protein sedimented on centrifugation of collapsed foams formed at $65^{\circ} \mathrm{C}$, followed by an increase in the amount of protein sedimented on centrifugation of foams formed at $85^{\circ} \mathrm{C}$ (Figure 4). This coincided with a progressive decrease in the stability of foams formed at 65 and $85^{\circ} \mathrm{C} .{ }^{1} \mathrm{H}$-Nuclear magnetic resonance studies (Rollema and Brinkhuis, 1989) have shown large increases in the spectral intensities and changes in the spectral characteristics of casein micelle suspensions in the temperature range from 60 to $98^{\circ} \mathrm{C}$, which have been attributed to the increasing mobility of proteins in the casein micelles with increasing temperature and the possible dissociation of caseins into the serum. Moreover, self-association of caseins at higher temperatures $\left(>50^{\circ} \mathrm{C}\right)$ has been reported as a result of increased side- chain mobility (Alaimo et al., 1999; Farrell et al., 2001). The self-association of caseins at elevated temperatures could decrease the availability of caseins for binding to and stabilizing the interface, thereby leading to a decrease in the stability of foams formed at 65 and $85^{\circ} \mathrm{C}$. The increase in the amount of protein sedimented from foams formed at $85^{\circ} \mathrm{C}$ compared with foams formed at $65^{\circ} \mathrm{C}$ is largely due to heat-induced formation of caseinwhey protein complexes in milk before foaming.

\section{Effect of Citrate and Calcium on the Foaming Properties of Milk}

Calcium plays an important role in determining the distribution of caseins between the serum and colloidal phases of milk (Augustin, 2000). Chelating of calcium by calcium-chelating agents leads to dissociation of casein micelles and thereby an increase in the serum casein content of milk. Addition of calcium to milk decreases the concentration of serum caseins and increases the micellar casein content of milk (Udabage et al., 2000). The effect of calcium and a calcium-chelating agent in the form of citrate on the foaming properties of the same lot of skim milk over a temperature range of 5 to $85^{\circ} \mathrm{C}$ was investigated to clarify whether dissociation of caseins is detrimental to foam stability while increases in the micellar casein content of milk increase foam stability.

\section{Effect of Added Citrate on the Foaming Properties of Milk}

The effect of temperature on the foamability and foam stability of milk, with and without added citrate is shown in Figures $4 \mathrm{a}$ and $4 \mathrm{~b}$ respectively. The foamability of milk with added citrate was similar to that of the control sample (Figure 4a). The foam stability of milk containing added citrate was very similar to the control sample when milk was foamed at 5,25 , and $85^{\circ} \mathrm{C}$ but lower than the control sample when the milk was foamed at 45 and $65^{\circ} \mathrm{C}$, with foam stability decreasing with increase in the concentration of the added citrate (Figure 4b).

Previous reports on the effect of added citrate on foaming properties of milk are conflicting. Kelly and Burgess (1978) and Lewis (1953) found increased rates of drainage in milk foams containing added citrate, whereas Buchanan (1965) found no change in the foaming properties of milk containing added citrate and foamed by injection of steam. Improvements in foamability and foam stability of skim milk containing added citrate on whipping at room temperature (Ward et al., 1997; Augustin and Clarke, 2008) and by foaming using steam (Augustin and Clarke, 2008) have been reported. 
In the present study, no improvement was observed in the foamability of milk containing added citrate and foamed in the temperature range from 5 to $85^{\circ} \mathrm{C}$. Foam stability did decrease for milk containing added citrate foamed at 45 and $65^{\circ} \mathrm{C}$ but did not change for milk containing added citrate foamed at 5,25 , and $85^{\circ} \mathrm{C}$ compared with the control milk. The type of method and equipment used to generate a foam influences foaming properties (Halling, 1981; Patino et al., 1995), making it difficult to make a direct comparison of results of the present study with results reported previously.

From the results of the present study, it appears that the dissociation of caseins from the micelle as a result of the addition of citrate has little effect on the stability of foams formed at 5,25 , and $85^{\circ} \mathrm{C}$, and has a destabilizing effect on foams formed at 45 and $65^{\circ} \mathrm{C}$. Lin et al. (1972) showed that addition of calcium-chelating agents led to the preferential loss of $\beta$-casein from the micelle. $\beta$-Casein is more surface-active than intact casein micelles (Zhang and Goff, 2004), and dissociation of caseins by added calcium-chelating agents could lead to increased adsorption of highly surface active $\beta$-casein. $\beta$-Casein is resistant to aggregation at the air-serum interface of milk foams compared with micellar caseins (Walstra, 1990) and, as a result, addition of calciumchelating agents leads to a decrease in foam stability when foams are formed at approximately $45^{\circ} \mathrm{C}$ where micellar aggregation is an important determinant of foam stability.

\section{Effect of Added Calcium Chloride on the Foaming Properties of Milk}

The effect of added calcium chloride on the foamability and foam stability of milk is shown in Figures $5 \mathrm{a}$ and $5 \mathrm{~b}$, respectively. The foamability of milk containing 10, 15, or $20 \mathrm{mM}$ added calcium chloride was very similar to that of the control milk (Figure 5a). However, the foam stability of milk containing added calcium chloride at 15 or $20 \mathrm{mM}$ was higher than for the control milk for foams formed at 25,45 , and $65^{\circ} \mathrm{C}$, with foam stability increasing with an increase in the concentration of added calcium chloride (Figure 5b). Milk containing 15 or $20 \mathrm{~m} M$ added calcium chloride coagulated when heated to $85^{\circ} \mathrm{C}$. The foam stability of milk containing $10 \mathrm{mM}$ added calcium chloride was very similar to that of the control milk, except for foam formed at $45^{\circ} \mathrm{C}$, which was slightly more stable (Figure $5 b)$.

The addition of calcium decreases the level of soluble caseins in milk (Rose, 1968; Lin et al., 1972; Lucey et al., 1997; Udabage et al., 2000). The lower foamability of milk containing 15 or $20 \mathrm{~m} M$ calcium chloride (Figure 5a) could be due to lower levels of serum casein. Casein
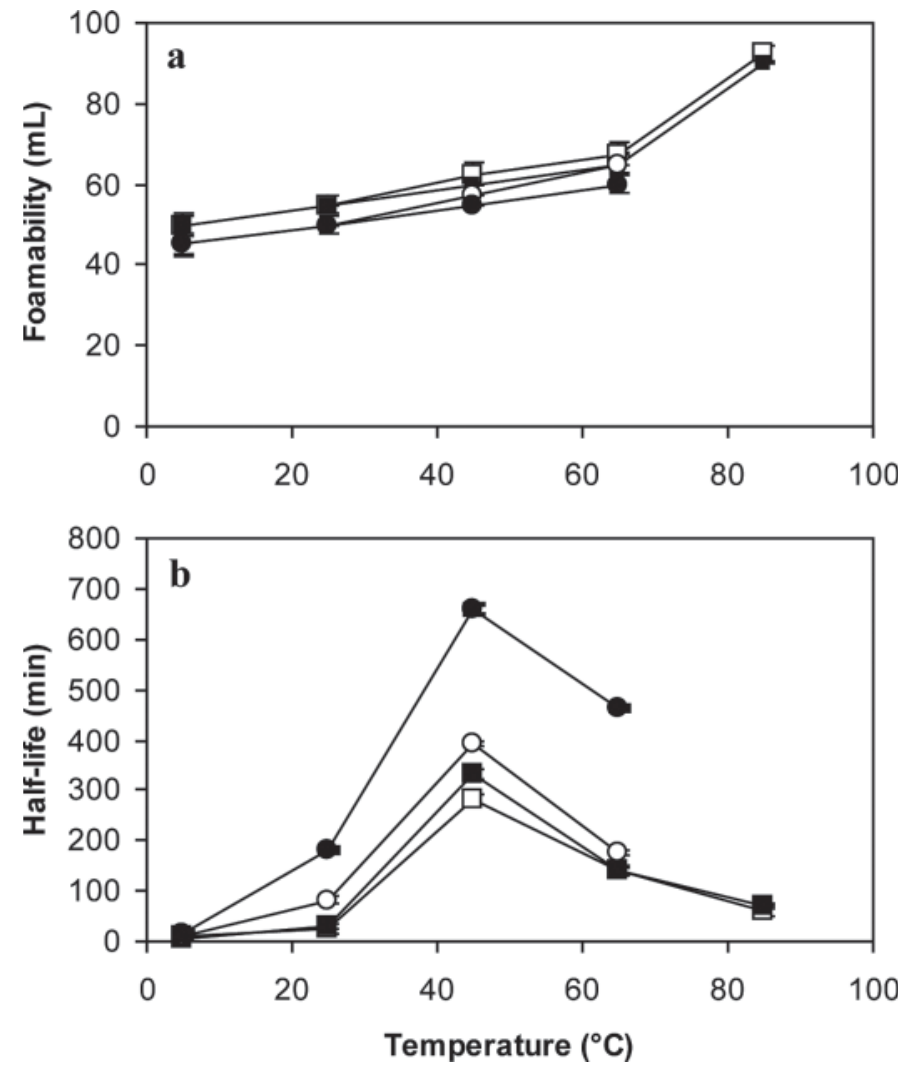

Figure 5. Foamability (a) and foam stability (half-life, b) of reconstituted low-heat skim milk powder (LHSMP) containing added calcium chloride. Values are the mean of 3 determinations $\pm \mathrm{SD}$, using the same lot of LHSMP. The range of percentage standard deviation for foamability and foam stability are 1 to $3 \%$ and 1 to $12 \%$, respectively.

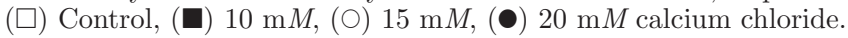

micelles are less surface-active than nonmicellar caseins and migrate more slowly to the air-serum interface of a foam (Zhang and Goff, 2004). Therefore, decreases in the levels of surface-active nonmicellar caseins, especially $\beta$-casein, could lead to decreased foamability of milk samples containing higher levels of added calcium chloride.

On the other hand, increases in the micellar casein content of milk as a result of calcium chloride addition increased the foam stability of milk. The increase in foam stability was most pronounced when foams were formed at 45 and $65^{\circ} \mathrm{C}$ (Figure 5b), where micellar aggregation at the air-serum interface is likely to occur. Zhang and Goff (2004) found that addition of calcium chloride to milk prevented dissociation of $\beta$-casein from the micelles, and no preferential adsorption of $\beta$-casein at the air-serum interface of milk foams was observed. Therefore, an increase in the micellar casein content of milk because of calcium chloride addition promotes greater micellar adsorption and aggregation at the interface, leading to the formation of more stable foam. Depression of foam formation on addition of calcium 


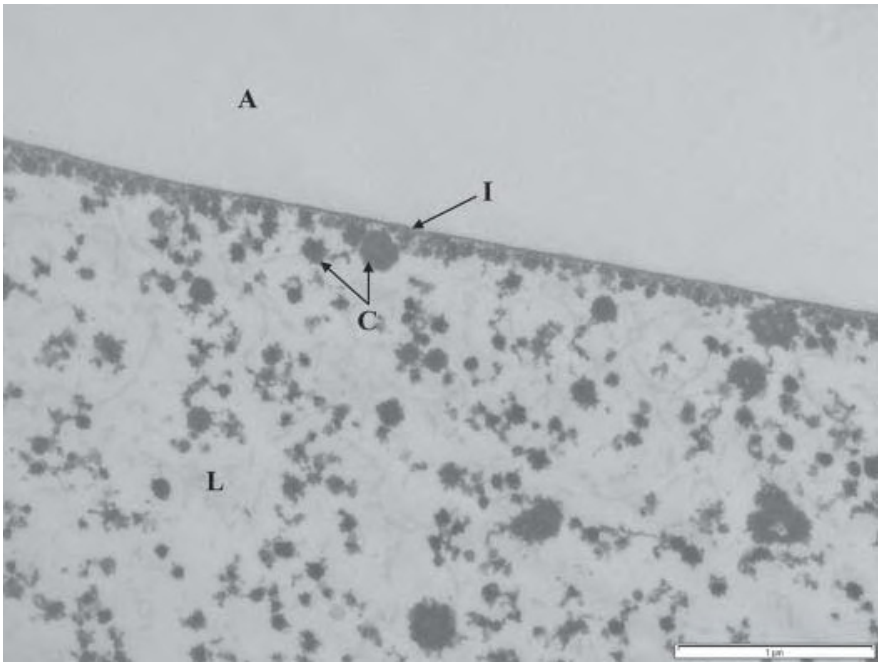

Figure 6. Air-serum interface of a bubble in skim milk foam. $\mathrm{A}=$ air, $\mathrm{L}=$ lamella, $\mathrm{I}=$ interface, $\mathrm{C}=$ casein micelle. $\mathrm{Bar}=1 \mu \mathrm{m}$.

chloride has been reported by Mohanty et al. (1988) and Augustin and Clarke (2008) on foaming of sodium caseinate solution and skim milk, respectively. As in the present study, Mohanty et al. (1988) found an increase in the foam stability of sodium caseinate solutions containing added calcium. The increase in foam stability was attributed to the aggregated state of casein as a result of added calcium chloride, leading to the formation of denser protein films.

Addition of calcium chloride had no effect on the stability of foams formed at $5^{\circ} \mathrm{C}$ (Figure $5 \mathrm{~b}$ ). Milk at $5^{\circ} \mathrm{C}$ contains the highest amount of serum casein, and the addition of calcium decreases the level of serum casein to a lesser extent than it would at higher temperatures

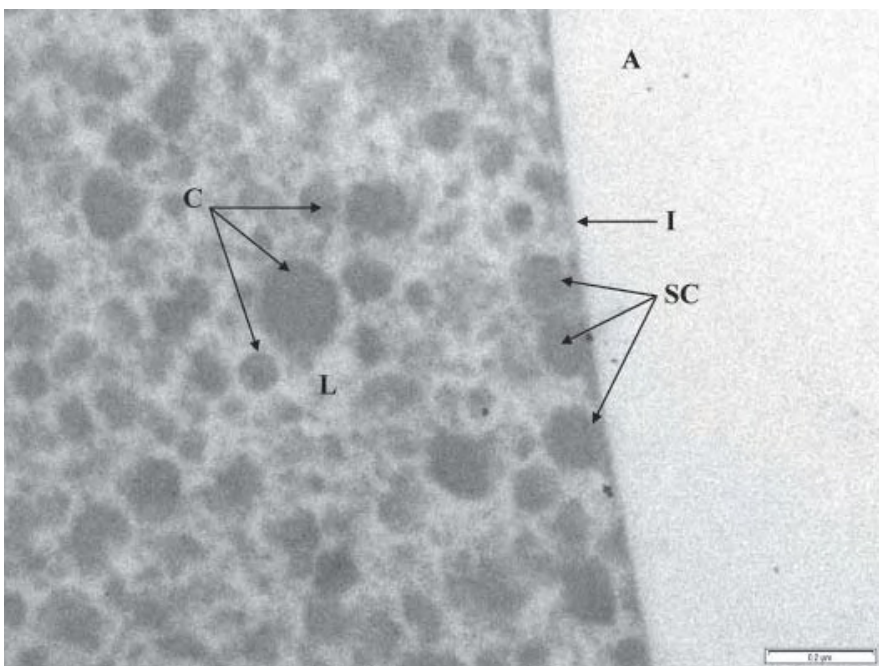

Figure 7. Spreading of casein micelles at the air-serum interface of a bubble in skim milk foam. $\mathrm{A}=$ air, $\mathrm{L}=$ lamella, $\mathrm{I}=$ interface, $\mathrm{SC}=$ spread casein micelle, $\mathrm{C}=$ casein micelle. $\mathrm{Bar}=0.2 \mu \mathrm{m}$.

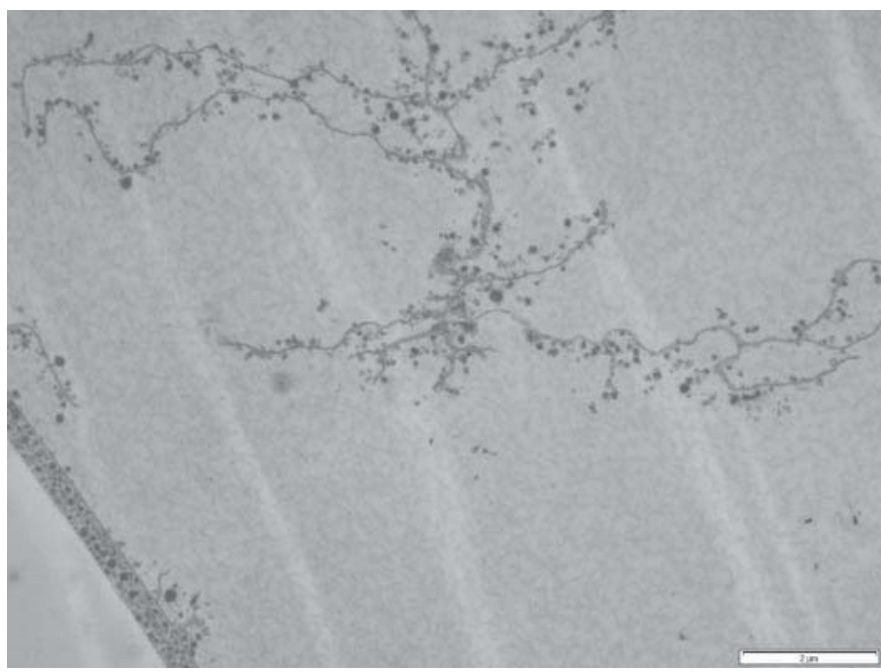

Figure 8. Collapsed interfacial membranes (bubble ghosts). Bar $=2 \mu \mathrm{m}$.

(Rose, 1968; Downey and Murphy, 1970). Moreover, an increase in micellar casein as a result of calcium addition is not beneficial to the stability of foams formed at lower temperatures, as discussed above. At $25^{\circ} \mathrm{C}$, an improvement in foam stability was observed on addition of 15 or $20 \mathrm{~m} M$ calcium chloride (Figure $5 \mathrm{~b}$ ). Milk contains less serum casein at $25^{\circ} \mathrm{C}$ than at $5^{\circ} \mathrm{C}$. Therefore, the addition of higher amounts of calcium chloride could reduce serum caseins to levels that are no longer detrimental to foam stability. Moreover, the increase in micellar casein as a result of calcium addition at $25^{\circ} \mathrm{C}$ could lead to greater adsorption and aggregation of casein micelles at the interface resulting in more stable foams.

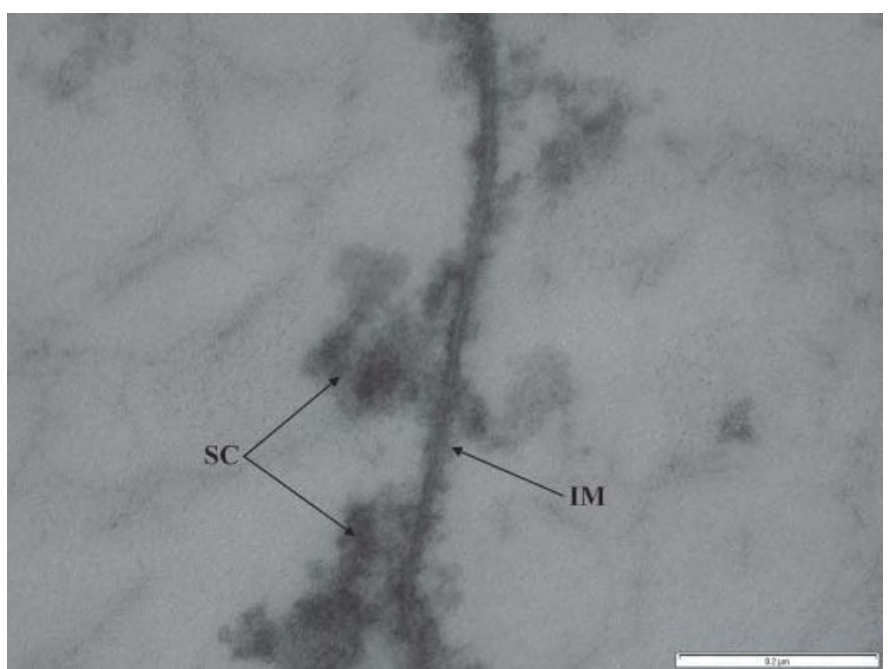

Figure 9. Spreading of casein micelles at the surface of collapsed interfacial membrane. $\mathrm{IM}=$ collapsed interfacial membrane, $\mathrm{SC}=$ spread casein micelles. Bar $=0.2 \mu \mathrm{m}$. 


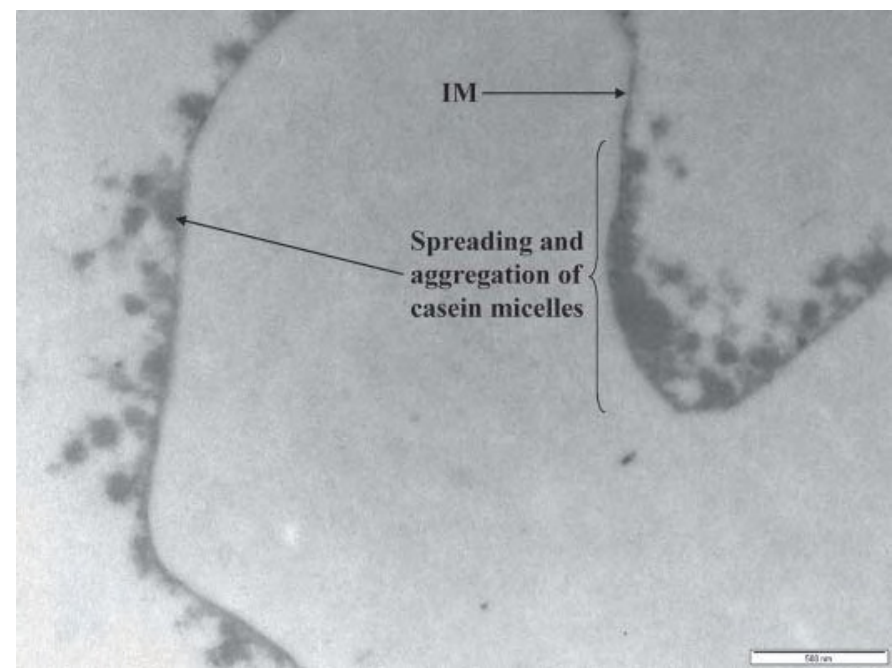

Figure 10. Spreading and aggregation of casein micelles at the surface of collapsed interfacial membranes. IM = interfacial membrane. Bar $=500 \mathrm{~nm}$.

\section{Transmission Electron Microscopy of Foams}

Transmission electron microscopy (TEM) of milk foam formed at $45^{\circ} \mathrm{C}$ was carried out to confirm the spreading of micellar casein described earlier. Figure 6 shows part of an air bubble, with the air-serum interface visible as a line of darkly stained material with an enrichment of casein micelles on the serum side of the interface. Based on previous TEM studies on milk foams performed by Brooker (1985) and Borcherding et al. (2008), it is likely that the line of darkly stained material is dissociated caseins and whey proteins, but its osmiophilicity could also partly be attributed to residual phospholipids present in skim milk (Ongun et al., 1968). Phospholipids are polar and have a high affinity for the air-serum interface of milk foams (Walstra et al., 1999; Huppertz, 2010). Brooker (1985) found that TEM images of milk foams formed at $6^{\circ} \mathrm{C}$ consisted of electron-dense material to which casein micelles were attached as a discontinuous layer. Borcherding et al. (2008) observed casein micelles as rough structures at the surface of the air bubble in TEM images of skim milk foams formed at $50^{\circ} \mathrm{C}$.

From Figure 7, it appears that casein micelles spread at the air-serum interface while attached to a pronounced line of darkly stained material. Intact sections of milk foam described above were difficult to obtain due to the delicate nature of the foam. However, several sections of ruptured air bubbles were obtained (which are likely to be the bubble ghosts observed by Brooker, 1985) and showed a layer of flocculated protein (Figure 8). This material also had a line of darkly stained protein to which spread and aggregated casein micelles were attached (Figures 9 and 10), suggesting that the adsorption and aggregation of micellar caseins at the interface was irreversible.

The above findings suggest that the primary airwater interface of skim milk foams formed at $45^{\circ} \mathrm{C}$ is made up of dissociated caseins and whey proteins; this observation is in line with the findings of Brooker (1985) and Borcherding et al. (2008). The interface may also contain polar lipids such as phospholipids (Huppertz, 2010). Micellar caseins, although not forming an integral part of the air-serum interface, contribute to the stability of milk foams formed at $45^{\circ} \mathrm{C}$ via adsorption-induced spreading and aggregation at the primary interface to form a more rigid film. Brooker (1985) did not find any evidence of micellar spreading or deformation at the interface in foams formed at $6^{\circ} \mathrm{C}$. This can be attributed to the inability of adsorbed casein micelles to aggregate at low temperatures when the colloidal stability of micelles is high (Walstra, 1990; Walstra et al., 1999). The role of casein micelles in stabilizing skim milk foams, by spreading at the interface, becomes evident only when milk foams are formed at higher temperatures, as in the present study.

\section{CONCLUSIONS}

Casein micelles play an important role in stabilizing the air-serum interface of milk foams, especially at temperatures $\geq 45^{\circ} \mathrm{C}$, via micellar spreading and aggregation at the air-serum interface of milk foam. Calcium-chelating agents appear to decrease foam stability by promoting dissociation of micellar casein, thereby decreasing micellar aggregation at the airserum interface of the foams. Conversely, addition of calcium appears to increase the stability of skim milk foams by increasing the levels of micellar casein. Interfacial material isolated by low-speed centrifugation of collapsed milk foams consisted almost entirely of casein. The TEM of milk foams confirmed the presence of casein micelles spread over the surface of foam bubbles formed at $45^{\circ} \mathrm{C}$. However, dissociated caseins and whey proteins may also help to stabilize milk foams formed at $\geq 45^{\circ} \mathrm{C}$.

\section{ACKNOWLEDGMENTS}

The authors gratefully acknowledge the technical expertise and assistance with the TEM experiments provided by Rick Webb (Centre for Microscopy and Microanalysis, University of Queensland, Brisbane, Australia) helpful discussions with Thom Huppertz (now at NIZO Research, Ede, the Netherlands), and valuable comments on interpretation of the electron micrographs by H. Douglas Goff (University of Guelph, 
Guelph, Ontario, Canada). The authors also thank Dairy Australia (Melbourne) for financial support.

\section{REFERENCES}

Alaimo, M. H., E. D. Wickham, and H. M. Farrell. 1999. Effect of selfassociation of alpha(s1)-casein and its cleavage fractions alpha(s1)casein(136-196) and alpha(s1)-casein(1-197), on aromatic circular dichroic spectra: Comparison with predicted models. Biochim. Biophys. Acta 1431:395-409.

Anderson, M., and B. E. Brooker. 1988. Dairy foams. Pages 221-255 in Advances in Food Emulsions and Foams. E. Dickinson and G. Stainsby, ed. Elsevier Applied Science, London, UK.

Anderson, M., B. E. Brooker, and E. C. Needs. 1987. The role of proteins in the stabilization/destabilization of dairy foams. Pages 100-109 in Food Emulsions and Foams. E. Dickinson, ed. Royal Society of Chemistry, London, UK.

Augustin, M. A. 2000. Mineral salts and their effect on milk functionality. Aust. J. Dairy Technol. 55:61-64.

Augustin, M. A., and P. T. Clarke. 2008. Skim milk powders with enhanced foaming and steam-frothing properties. Dairy Sci. Technol. 88:149-161.

Borcherding, K., P. C. Lorenzen, W. Hoffmann, and K. Schrader. 2008. Effect of foaming temperature and varying time/temperature conditions of pre-heating on the foaming properties of skimmed milk. Int. Dairy J. 18:349-358.

Brooker, B. E. 1985. Observations on the air-serum interface of milk foams. Food Microstruct. 4:289-296.

Buchanan, R. A. 1965. Lipolysis and the frothing of milk. Aust. J. Dairy Technol. 20:62-66.

Damodaran, S. 1997. Protein-stabilized foams and emulsions. Pages 57-110 in Food Proteins and their Application. S. Damodaran and A. Paraf, ed. Marcel Dekker, New York, NY.

Darling, D. F., and D. W. Butcher. 1978. Milk fat globule membrane in homogenized cream. J. Dairy Res. 45:197-207.

de Wit, J. N. 1990. Thermal stability and functionality of whey proteins. J. Dairy Sci. 73:3602-3612.

Dickinson, E. 1992. Emulsifying and foaming properties of proteins. Food Sci. Technol. Today 6:152-155.

Downey, W. K., and R. F. Murphy. 1970. Temperature dependent dissociation of $\beta$-casein from bovine casein micelles and complexes. J. Dairy Res. 37:361-372.

Farrell, H. M., E. D. Wickham, J. J. Unruh, P. X. Qi, and P. D. Hoagland. 2001. Secondary structural studies of bovine caseins: Temperature dependence of beta-casein structure as analyzed by circular dichroism and FTIR spectroscopy and correlation with micellization. Food Hydrocoll. 15:341-354.

Halling, P. J. 1981. Protein-stabilized foams and emulsions. Crit. Rev. Food Sci. Nutr. 15:155-203.

Holt, C. 1995. Effect of heating and cooling on the milk salts and their interaction with casein. Pages 105-133 in Heat-Induced Changes in Milk. 2nd ed. P. F. Fox, ed. International Dairy Federation, Brussels, Belgium.

Huppertz, T. 2010. Foaming properties of milk: A review of the influence of composition and processing. Int. J. Dairy Technol. 63:477-488.

Jenness, R., and J. Koops. 1962. Preparation and properties of a salt solution which simulates milk ultrafiltrate. Neth. Milk Dairy J. $16: 153-164$.

Jeurnink, T. J. M. 1995. Fouling of heat exchangers by fresh and reconstituted milk and the influence of air bubbles. Milchwissenschaft 50:189-193.

Kamath, S., T. Huppertz, A. V. Houlihan, and H. C. Deeth. 2008. The influence of temperature on the foaming of milk. Int. Dairy J. $18: 994-1002$.

Kelly, P. M., and K. J. Burgess. 1978. Foaming properties of milk protein concentrate prepared by ultrafiltration. Irish J. Food Sci. Tec. 2:93-104.
Kilara, A., and V. R. Harwalkar. 1996. Denaturation. Pages 71-165 in Food Proteins: Properties and Characterization. S. Nakai and H. W. Modler, ed. VCH Publishers, New York, NY.

Law, A. J. R. 1996. Effects of heat treatment and acidification on the dissociation of bovine casein micelles. J. Dairy Res. 63:35-48.

Law, A. J. R., D. S. Horne, J. M. Banks, and J. Leaver. 1994. Heat induced changes in the whey proteins and caseins. Milchwissenschaft 49:125-129.

Lewis, M. A., V. Marcelli, and B. M. Watts. 1953. Stable foams from food proteins with polyphosphates. Food Technol. 7:261-264.

Lin, S. H. C., S. L. Leong, R. K. Dewan, V. A. Bloomfield, and C. V. Morr. 1972. Effect of calcium ion on structure of native bovine casein micelles. Biochemistry 11:1818-1821.

Lowry, O. H., N. J. Rosebrough, A. L. Farr, and R. J. Randall. 1951. Protein measurement with the folin phenol reagent. J. Biol. Chem. 193:265-275.

Lucey, J. A., C. Dick, H. Singh, and P. A. Munro. 1997. Dissociation of colloidal calcium phosphate-depleted casein particles as influenced by $\mathrm{pH}$ and concentration of calcium and phosphate. Milchwissenschaft 52:603-606.

Mohammad, K. S., and P. F. Fox. 1987. Heat-induced associationdissociation of casein micelles preceding coagulation. J. Dairy Res. 54:377-387.

Mohanty, B., D. M. Mulvihill, and P. F. Fox. 1988. Emulsifying and foaming properties of acidic caseins and sodium caseinate. Food Chem. 28:17-30.

Mulder, H., and P. Walstra. 1974. The Milk Fat Globule: Emulsion Science as Applied to Milk Products and Comparable Foods. PUDOC, Wageningen, the Netherlands.

Ongun, A., W. W. Thomson, and J. B. Mudd. 1968. Lipid fixation during preparation of chloroplasts for electron microscopy. J. Lipid Res. 9:416-424.

Oortwijn, H., and P. Walstra. 1979. Membranes of recombined fat globules. 2. Composition. Neth. Milk Dairy J. 33:134-154.

Patino, J. M. R., M. D. N. Delgado, and J. A. L. Fernandez. 1995. Stability and mechanical strength of aqueous foams containing food proteins. Colloids Surf. A Physicochem. Eng. Asp. 99:65-78.

Rollema, H. S., and J. A. Brinkhuis. 1989. A ${ }^{1}$ H-NMR study of bovine casein micelles; influence of $\mathrm{pH}$, temperature and calcium ions on micellar structure. J. Dairy Res. 56:417-425.

Rombaut, R., and K. Dewettinck. 2006. Properties, analysis and purification of milk polar lipids. Int. Dairy J. 16:1362-1373.

Rose, D. 1968. Relation between micellar and serum casein in bovine milk. J. Dairy Sci. 51:1897-1902.

Sharp, P. F., R. P. Myers, and E. S. Guthrie. 1936. Accumulation of protein in the foam of skim milk. J. Dairy Sci. 19:655-662.

Singh, H. 1995. Heat-induced changes in casein, including interactions with whey proteins. Pages 86-104 in Heat-Induced Changes in Milk. 2nd ed. P. F. Fox, ed. International Dairy Federation, Brussels, Belgium.

Udabage, P., I. R. McKinnon, and M. A. Augustin. 2000. Mineral and casein equilibria in milk: Effects of added salts and calciumchelating agents. J. Dairy Res. 67:361-370.

Walstra, P. 1990. On the stability of casein micelles. J. Dairy Sci. 73:1965-1979

Walstra, P. 1999. Casein sub-micelles: Do they exist? Int. Dairy J. 9:189-192.

Walstra, P., T. J. Geurts, A. Noomen, A. Jellema, and M. A. J. S. vanBoekel. 1999. Dairy Technology: Principles of Milk Properties and Processes. Marcel Dekker Inc., New York, NY.

Ward, B. R., S. J. Goddard, M. A. Augustin, and I. R. McKinnon. 1996. Distribution of proteins in concentrated skim milk reconstituted from low- and high-heat milk powders. J. Dairy Res. 63:643-648

Ward, B. R., S. J. Goddard, M. A. Augustin, and I. R. McKinnon 1997. EDTA-induced dissociation of casein micelles and its effect on foaming properties of milk. J. Dairy Res. 64:495-504.

Zhang, Z., and H. D. Goff. 2004. Protein distribution at air interfaces in dairy foams and ice cream as affected by casein dissociation and emulsifiers. Int. Dairy J. 14:647-657. 